\title{
Carbon Monoxide Consumption in Digestate and its Potential Applications
}

\author{
혐기성 소화액에서 일산화탄소 소비특성 분석과 그 활용 방안
}

\author{
Hong, Seonggu, ${ }^{*+}$ \\ 홍성구,+,
}

\begin{abstract}
Acetogen과 같은 일부 혐기성미생물은 소위 acetyl-CoA 경로에 의해 아세트산, 에탄올, 그리고 몇 가지 생화학 물질을 생산한 다. 이 경로에서는 일산화탄소를 기질로 이용할 수 있다. 일산화탄소 이외에 수소가 이용될 수 있다. 즉, 이들 미생물은 독립영 양생물로서 이산화탄소와 태양광에너지를 이용하는 녹색식물과 비유될 수 있으며, 일산화탄소는 탄소원으로서 둥시에 에너지원 으로서 이용된다. 본 연구에서는 혐기성 소화액 중 아세트산을 생성하는 미생물이 존재한다고 가정하고, 일산화탄소와 수소가 주 가연성분인 합성가스를 공급하면 추가의 메탄이 생성가눙성을 평가하였다. 혐기성 소화과정에서 발생되는 메탄은 주로 아세 트산으로부터 만들어지므로 일산화탄소를 공급하는 경우 추가로 메탄이 생성될 것으로 추측할 수 있기 때문이다. 이를 확인하 기 위하여 현재 운영중인 바이오가스 생산 설비로부터 얻은 협기성 소화액을 생물반웅조에 넣은 후, 합성가스를 순환-공급하여 가스 생산량의 변화 및 조성을 분석하였다. 질소가스를 공급한 대조구와는 달리 일산화탄소 또는 합성가스를 공급한 경우에는 메탄가스가 생산되는 것을 확인하였다. 일산화탄소만을 공급했을 때에는 이산화탄소의 생성으로 가스 생산량이 중가하였으나, 수소가 포함된 합성가스를 공급하였을 때에는 이산화탄소가 탄소원이로 소비되어 가스 저장조 내의 가스량이 감소하는 것을 확 인할 수 있었다. 가스화공정에 의해 얻어지는 합성가스는 온도와 가스 조성을 고려할 때, 바이오가스 생산을 위한 험기성 소화 조와 연계하면 소화조의 가온에 필요한 열을 공급할 수 있고 바이오가스 중 이산화탄소 농도를 낯추어 발열량을 개선할 수 있 을 것으로 판단된다.
\end{abstract}

Keywords: Acetogens; gasification; anaerobic digestion; fermentation; bioreactor

\section{INTRODUCTION}

Gasification is a century old technology to produce combustible producer gas from solid fuels including coals, biomass, and municipal wastes. Major combustible components are carbon monoxide and hydrogen in the gas. The producer gas can be used to fuel engines for heat and/or power, or to produce synthetic fuels through chemical processes. In some countries where sufficient amount of biomass is available, gasification plants are in

* 한경대학교 농업생명과학대학 지역자원시스템공학과

+ Corresponding author. Tel.: +81-31-670-5134

Fax: +81-31-674-4119

E-mail address: bb9@hknu.ac.kr

2008년 12월 17일 투고

2009년 2월 3일 심사완료

2009년 2월 3일 게재확정 operation to provide gaseous fuel for community heating or cooking. However, there are some limitations and problems that should be considered when planning gasification projects. The gas has relatively lower calorific values, about $4-7 \mathrm{MJ} / \mathrm{Nm}^{3}$ from air gasification and $10-$ $18 \mathrm{MJ} / \mathrm{Nm}^{3}$ from oxygen gasification (EBIA, 2007). Tar, particulates, and alkali metals are contaminants that need to be removed in order not to affect or corrode major parts of appliances.

Fuels and chemical products can be produced using the syngas. The production of methanol or DME(dimethylether) is an example of the processes. Fischer-Tropsch(F-T) process is another example for producing fuels for transportation using the syngas. The syngas should be purified so that the contamination of catalyst could be 
minimized in the chemical processes. Biological processes in producing chemicals or fuels using syngas have some advantages over chemical processes. Chemical catalyst is easily poisoned by sulfide compound such as hydrogen sulfide, and CO/hydrogen ratio of the feed gas is important in the process. Meanwhile biological processes are tolerant to these constraints. Recently, biological processes using the syngas were proposed to produce chemicals and ethanol, using autotrophic microbes such as acetogens.

Acetogens refer to bacteria that generate acetate as a product of anaerobic respiration. Acetogenic metabolism utilizes $\mathrm{CO}_{2}$ as one of major carbon sources and requires hydrogen as an energy source. Their substrates include the mixture of carbon dioxide and hydrogen, carbon monoxide, the mixture of methanol and carbon dioxide. Acetogens have the following stoichiometry at the expense of hydrogen and carbon dioxide,

$$
4 \mathrm{H}_{2}+2 \mathrm{CO}_{2} \rightarrow \mathrm{CH}_{3} \mathrm{COOH}+2 \mathrm{H}_{2} \mathrm{O}
$$

The pathway is called acetyl-CoA pathway since carbon dioxide is reduced to the acetyl moiety of acetyl-coenzyme A (CoA), to conserve energy, and to construct cell biomass. Sulfidogens, methanogens, and homoacetogens are the lithotrophs that take the acetylCoA pathway. The pathway is sometimes called CODH (Carbon monoxide dehydrogenase) pathway due to its importance role in the pathway, or Wood-Ljungdahl pathway to recognizing their efforts in resolving the process. Several microbes were found that rely on $\mathrm{CO}$ or $\mathrm{CO}_{2} /$ hydrogen for their carbon and energy sources through the acetyl-CoA pathway. Clostridium ljungdahlii and Clostridium autoethanogenum are the examples that can be used in biological processes in producing ethanol. CO-dependent acetogens have the following stoichiometry,

$$
4 \mathrm{CO}+2 \mathrm{H}_{2} \mathrm{O} \rightarrow \mathrm{CH}_{3} \mathrm{COOH}+2 \mathrm{CO}_{2}
$$

Phillips et al. (1994) showed that Clostridium ljungdahlii can be used to produce ethanol and acetate by syngas fermentation. Cotter and Chinn (2008) reported that ethanol and acetate productions by Clostridium ljungdahlii were 5.2 and $40.1 \mathrm{mM}$, respectively. The thermophillic bacterium Moorella sp. HUC22-1 is reported to produce $120 \mathrm{mM}$ acetate and $5.2 \mathrm{mM}$ ethanol(Inokuma et al., 2007). For CO substrate and acetate production considering cell mass produced, the molar stoichiometry is (Brown, 2006),

$$
4 \mathrm{CO} \rightarrow 2.17 \mathrm{CO}_{2}+0.74 \mathrm{CH}_{3} \mathrm{COOH}+0.45 \mathrm{Cell}
$$

where Cell indicates carbon equivalents in the cell mass produced. For $\mathrm{CO}$ and hydrogen is provided, the stoichiometry is,

$$
2 \mathrm{H}_{2}+1.03 \mathrm{CO} \rightarrow 0.43 \mathrm{CH}_{3} \mathrm{COOH}+0.13 \mathrm{Cell}
$$

Unlike acetogenic metabolism, Anaerobic digestion produces methane in degrading organic materials. Methanogen utilizes $\mathrm{CO}_{2}$, methyl groups such as methanol and methylamine, acetate as carbon sources. Hydrogen is the energy source for methanogen that reduces $\mathrm{CO}_{2}$ into methane. Aceticlastic methanogen utilizes acetate, which includes Methanosarcina and Methanosaeta/Methanothrix (Kim, 2005). In anaerobic digestion, over $70 \%$ of methane is produced from acetate(Yang and Lee, 2004). Therefore, it can be expected that additional methane can be produced if extra acetate is provided through CO fermentation by acetogenic bacteria. Methane production in anaerobic digestion system has the following net stoichiometry when CO fermentation is incorporated ignoring cell mass production,

$$
4 \mathrm{CO}+2 \mathrm{H}_{2} \mathrm{O} \rightarrow \mathrm{CH}_{4}+3 \mathrm{CO}_{2}
$$

Additionally, heat obtained from cooling syngas can be used in digester heating when digester and gasification system are coupled. In this study, it is hypothesized that additional methane can be produced by CO supply to anaerobic digestate. It seems that there are no studies on incorporating producer gas into anaerobic digester to increase methane production. This paper shows a preliminary result on the $\mathrm{CO}$ fermentation experiments to test the hypothesis. Some suggestions for coupling or 
parallel operation of gasification and anaerobic digestion are presented for practical applications.

\section{MATERIALS AND METHODS}

CO fermentation experiments were conducted using liquid digestate obtained from digester operated by Biogas Research Center of Hankyong National University. The digestion system has a $150 \mathrm{~m}^{3}$ of digester with about $5 \mathrm{~m}^{3}$ of daily inflow of pig manure. Tubular bioreactor systems were manufactured for the experiments(Fig. 1). The reactors have $9.9 \mathrm{~cm}$ of internal diameter and $39.3 \mathrm{~cm}$ of height. Each reactor has a separate gas storage on top of the reactor of $3,225 \mathrm{~cm}^{3}$ of volume. The storage cap is sealed with water and can be easily moved up or down by net gas production or consumption (Fig. 2 (b)). A peristaltic pump was installed to circulate the gas. The reactors were placed inside a commercial BOD incubator in order to keep the reactors under the controlled temperatures (Fig. 2 (a)).

Nitrogen gas was filled in the gas storage of a control reactor. Manufactured syngas was supplied to the other reactor. The syngas has $29.9 \%$ of hydrogen, $50.2 \%$ of $\mathrm{CO}$, and nitrogen for balance. The manufactured gas was used in the first half of experiments, and $100 \%$ CO gas was used in the following set of experiments. The gases

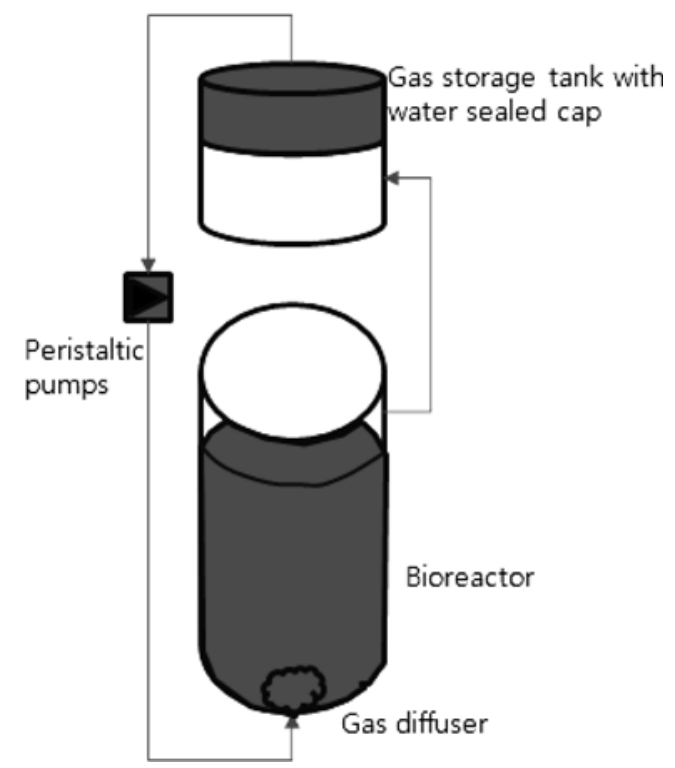

Fig. 1 Diagram for experimental setup

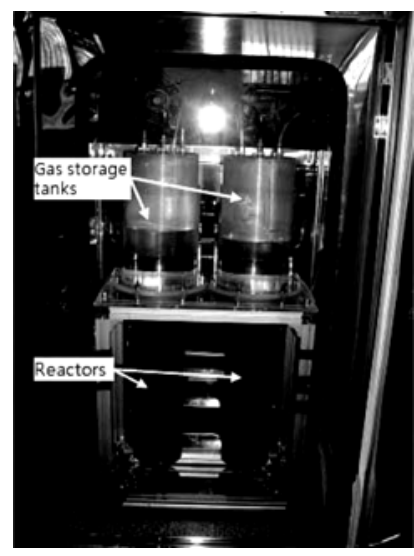

(a) Bioreactors

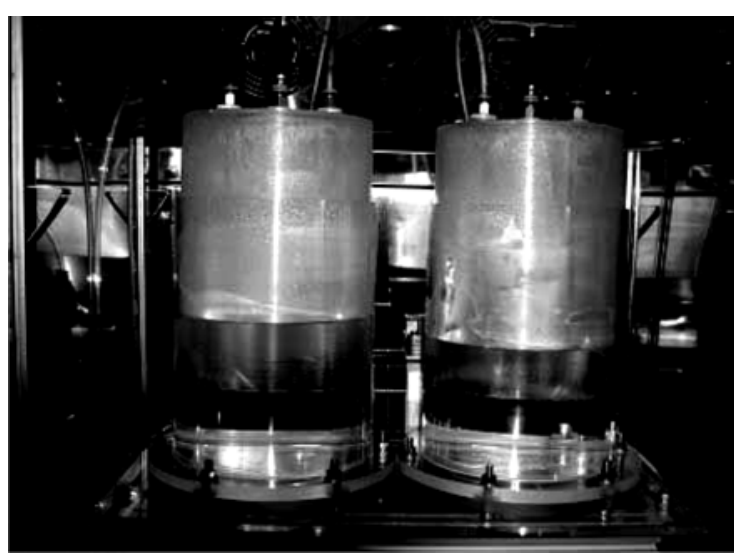

(b) Gas storage tanks

Fig. 2 Bioreactors integrated with gas storage tank installed inside incubator.

were supplied to the reactors through the ceramic diffuser placed at the bottom of reactors continuously. The changes in gas storage were measured and gas composition was analyzed for methane, carbon monoxide, and carbon dioxide. Gas detection tubes (Gastec, Japan) and monitoring sensors were used in analyzing the gas composition. Model $1 \mathrm{HH}$ and $2 \mathrm{H}$ of the detector tubes were used for carbon monoxide and carbon dioxide, respectively. Methane concentration was measured using a gas analyzer, Delta 1600-S (MRU, Germany), which was adjusted to measure up to $100 \%$ of methane.

Each set of experiments was continued until the volume of gas storage was stable for a while or the storage cap reached the bottom. The pump for gas circulation continued to run for the entire period of each experiment. The changes in the height of storage cap were measured 
every 30 minutes. The gas composition was analyzed after turning off the circulation pump at the end of experiments. Three sets of experiments were conducted to see the changes in the storage volume in August, and four sets were for both gas composition and changes in gas volume in October and November.

\section{RESULTS AND DISCUSSION}

\section{Changes in gas storage volume}

Gas volume was increased as soon as gas circulation started in all $\mathrm{N}_{2}$-fed control experiments. Respiration of bacteria seems to result in the production of carbon dioxide and increases in the volume of gas storage. Gas production is observed in both reactors, while gas consumption is dominant under manufactured gas supply. Decrease in gas storage volume indicates that consumptions of $\mathrm{CO}$ and hydrogen gases masked the production of $\mathrm{CO}_{2}$ microbial respiration. The control reactor also shows a slight decrease in gas volume over the time.

Fig. 3 is one example of changes in the gas storage. The height of storage cap indicates the storage volume of gas in the graph. Each experiment had differences in the changes. The results of experiments conducted in August showed similar changes in storage volume. As shown in the Fig. 3, for syngas case, the storage volume was decreased by about 15\% within two hours. In spite of $\mathrm{CO}_{2}$ production by respiration, net changes in gas volume were decreased. However, $\mathrm{N}_{2}$-fed reactors had

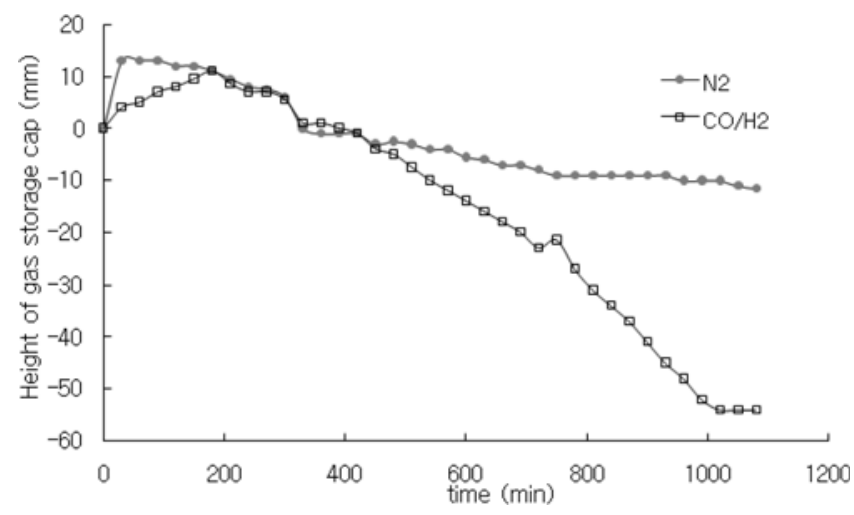

Fig. 3 Changes in gas storage volume in the height of storage cap (filled square $-\mathrm{CO}$ and $\mathrm{H}_{2}$, circle $-\mathrm{N}_{2}$ )

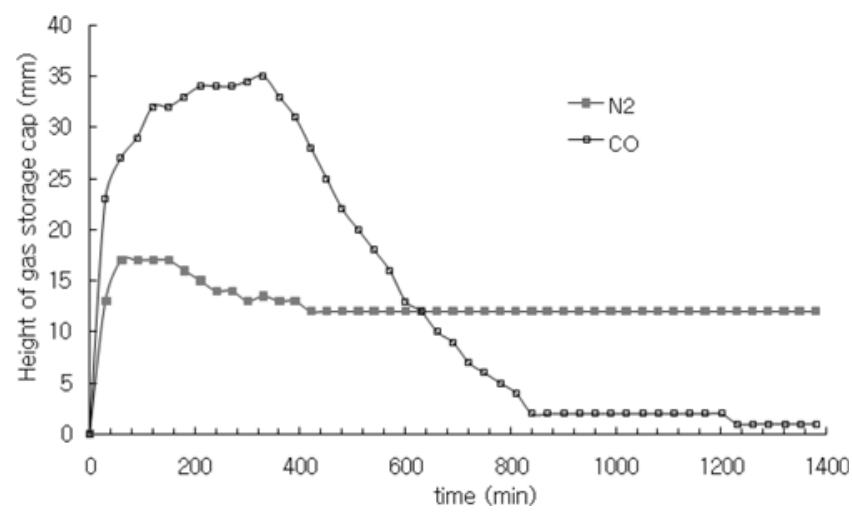

Fig. 4 Changes in gas storage volume by the height of cap (CO 100\%)

net increases in gas production in the beginning stage. The gas volume began to decrease after the peak of the volume. The decrease in gas storage in $\mathrm{N}_{2}-$ fed reactor seems to indicate that $\mathrm{CO}_{2}$ was consumed inside the reactor.

The experiments conducted in October and November showed quite different changes in gas volume. The gas production, assuming $\mathrm{CO}_{2}$, was much greater than that of the previous experiments. The fermentation experiments were conducted immediately after liquid digestate sampling without the interval of storage. Net production of gas was dominant in both reactors. Unlike previous experiments as shown in Fig. 3, gas storage volume has a net increase in both $\mathrm{N}_{2}$ and syngas cases as shown in Fig. 4, seemingly because manufactured syngas was used. When $\mathrm{CO}$ is assimilated, $\mathrm{CO}_{2}$ is produced as in equation 2). Meanwhile, $\mathrm{CO}_{2}$ is consumed when $\mathrm{H}_{2}$ is supplied as in equation 1).

\section{Gas compositions}

Gas composition analyzed in the experiments showed the productions of methane and decreases in carbon monoxide. Methane concentration was between 1 and $10 \%$ in CO-fed reactors, while $\mathrm{N}_{2}$-fed reactors have $0.05 \sim 0.98 \%$ as shown in Fig. 5. $\mathrm{CO}_{2}$ concentrations were increased up to $12 \sim 41 \%$ for $\mathrm{CO}$-fed cases, and about $20 \%$ for the control reactors. Initially, there were no $\mathrm{CO}_{2}$ in the storage tanks. Final $\mathrm{CO}$ concentrations ranged between $12 \%$ and $45 \%$. That is, 55 to $88 \%$ of $\mathrm{CO}$ was 


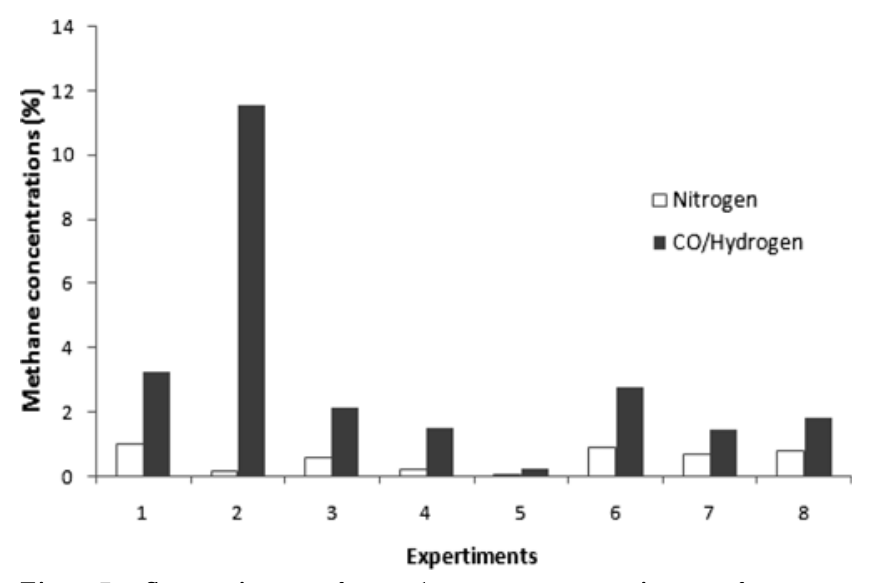

Fig. 5 Comparison of methane concentrations after gas circulations with nitrogen and syngas.

consumed by bacteria inside the reactors. Based on the gas composition, it is certain that $\mathrm{CO}_{2}$ production by cell respiration exists. For the control cases with nitrogen only, methane was produced even if its rate is quite low. It is not clear why the net storage volume continues to decrease after the increase in the beginning of fermentation in the control experiments. In some experiments, net decrease of gas volume was observed, which indicates the consumption of nitrogen. These questions need further investigations.

\section{Mass conversion}

The volume of $\mathrm{CH}_{4}$ and $\mathrm{CO}_{2}$ produced during the fermentation was calculated using the reading of storage cap height and the concentration of each gas. Methane production rate was $3 \sim 15.6 \mathrm{ml} / \mathrm{hr}, \mathrm{CO}_{2} 18 \sim 90 \mathrm{ml} / \mathrm{hr}$, and CO consumption rate was $77 \sim 190 \mathrm{ml} / \mathrm{hr}$ as shown in Table 1. Bacterial cell growth was not measured in this study. Cell biomass and other organic compounds may be helpful for further analysis. Based on gas production and consumption rates, an approximate stoichiometry is,

$$
(17 \sim 25) \mathrm{CO} \rightarrow \mathrm{CH}_{4}+(5 \sim 8) \mathrm{CO}_{2}+\text { Cell biomass }
$$

As mentioned in the previous section, $\mathrm{N}_{2}$-fed reactors also have methane productions. Equation 6) did not account this into account. The net production rate of $\mathrm{CH}_{4}$ would be lower than the experimental results when
Table 1 Production and consumption rates of gas for fermentation experiments

\begin{tabular}{c|r|r|r|r|r|r}
\hline \multirow{2}{*}{ Time(hour) } & \multicolumn{3}{|c|}{$\begin{array}{c}\text { Changes in volume of gas } \\
\text { (ml) }\end{array}$} & \multicolumn{1}{|c}{$\begin{array}{c}\text { Gas production/consumption rate } \\
\text { (ml/hr) }\end{array}$} \\
\cline { 2 - 7 } & \multicolumn{1}{c|}{$\mathrm{CO}$} & \multicolumn{1}{c|}{$\mathrm{CH}_{4}$} & \multicolumn{1}{c|}{$\mathrm{CO}_{2}$} & \multicolumn{1}{c|}{$\mathrm{CO}$} & \multicolumn{1}{c}{$\mathrm{CH}_{4}$} & \multicolumn{1}{c}{$\mathrm{CO}_{2}$} \\
\hline \hline 23 & 1777.34 & 68.99 & 424.06 & 77.28 & 3.00 & 18.44 \\
\hline 14 & 2439.70 & 104.67 & 1253.73 & 174.26 & 7.48 & 89.55 \\
\hline 10.5 & 1998.98 & 74.14 & 333.05 & 190.38 & 7.06 & 31.72 \\
\hline 22 & 2874.85 & 343.01 & 976.12 & 130.67 & 15.59 & 44.37 \\
\hline average & 2072.01 & 82.60 & 670.28 & 143.15 & 8.28 & 46.02 \\
\hline
\end{tabular}

the $\mathrm{CH}_{4}$ production in the control cases is subtracted. Then, CO consumption rate could be increased for the production of the same mole of methane. Since there are unexplained variations in the experimental results, further works should be followed and combined to reach a clear explanation for this process.

\section{Potential applications and problems}

In this study with a limited number of experiments, we could see the additional production of methane through supplying $\mathrm{CO}$ and manufactured syngas into liquid slurry obtained from anaerobic digester. Although the result, in terms of production rates of methane, was not satisfactorily large, it indicates that syngas could be supplied into liquid digestate to produce additional methane or biogas. Whether or not the syngas-fed digestion system is feasible, there are potential benefits from combining thermo-chemical gasification and anaerobic digestion systems.

The first of the benefits is heat recovery from syngas cooling. Most of anaerobic digestion systems are mesoor thermophilic. They require heating during a certain period of time of a year, especially in thermophilic systems. The temperature of the syngas exited from a gasifier is very high, reaching over $400^{\circ} \mathrm{C}$. In cold region or season, heat supply from syngas cooling could help improve overall economy of the system. The syngas can be supplied though a gas-circulating mixing system. In this case, no additional gas circulating system would be required. An integrated organic resources/wastes management plant can be planned at one station through integrating the two systems. Wet stream of waste is fed 
into anaerobic digestion system, while dry or the other solid combustible waste is fueled into the gasification system. In this case, a single heat and/or power system can be shared for the operation with both methane based biogas and syngas fueled.

Meanwhile, $\mathrm{CO}_{2}$ concentration could be increased in the digester gas as $\mathrm{CO}$ fermentation takes place. As shown in the previous section, the volume of $\mathrm{CO}_{2}$ is more than five times greater than that of methane produced at a given mole of CO consumption when $100 \%$ of CO was supplied. This results in higher concentration of $\mathrm{CO}_{2}$ in biogas, which is not desirable for gas utilization. Future investigations need to include the effect of syngas composition on $\mathrm{CO}_{2}$ production rates.

\section{CONCLUSIONS}

In this study, it was hypothesized that additional methane could be produced by $\mathrm{CO}$ supply into anaerobic digestate for fermentation. The fermentation is based on AcetylCoA pathway, using carbon monoxide ( $\mathrm{CO}$ ) as a main substrate. They rely on $\mathrm{CO}$ for their carbon and energy sources. Acetate is the major source in producing methane in anaerobic digestion. For testing the research hypothesis, in this study, changes in gas composition were investigated as CO was supplied in a bioreactor. A preliminary result based on a limited number of $\mathrm{ex}^{-}$ periments showed that additional production of methane was observed through $\mathrm{CO}$ fermentation, which was compared with the control experiments fed with $\mathrm{N}_{2}$ gas only.

Net decrease in gas storage volume was observed in spite of $\mathrm{CO}_{2}$ production through cell respiration in syngas-fed reactor. There exist substantially more productions of methane compared to those from the control. Methane production rate was $3 \sim 15.6 \mathrm{ml} / \mathrm{hr}, \mathrm{CO}_{2}$ 18 90 $\mathrm{ml} / \mathrm{hr}$, and CO consumption rate was $77 \sim 190 \mathrm{ml} / \mathrm{hr}$. More $\mathrm{CO}$ was used in unit $\mathrm{CH}_{4}$ production in the fermentation, compared to the theoretical stoichiometry.

Whether or not the syngas-fed digestion system is feasible, some suggestions for coupling or parallel operation of gasification and anaerobic digestion are presented for practical applications. The first of the benefits is heat recovery from syngas cooling for the use of digester heating. Although syngas fermentation is drawing many interests due to its potential of producing ethanol from biomass and wastes, coupled operation of a gasifier with an existing digester system could be another green alternative to improve overall economy of anaerobic digestion systems.

\section{REFERENCES}

1. Brown, R., 2006. Biorefineries based on thermochemical processing. in Biorefineries - Industrial Processes and Products. ed. Kamm, B., P. R. Gruber, and M. Kamm. Wiley-VCH Verlag GmbH \& Co. KGaA.

2. Cotter, J. L. and M. S. Chinn. 2008. Ethanol and acetate production by Clostridium ljungdahlii and Clostridium autoethanogenum using resting cells. Bioprocess and Biosystems Engineering, 10.1007/ s00449-008-0256-y.

3. EBIA - European Biomass Industry Association. 2007. Gasification. Http://www.eubia.org/210.0htm. Accessed 10 Aug. 2008.

4. Inokuma, K., Y. Nakashimada, T. Akahoshi, and N. Nishio, 2007. Characterization of enzymes involved in the ethanol production of Moorella sp. HUC22-1. Archives of Microbiology 188: 37-45.

5. Kim, B. H., 2005. Microbial Physiology. Academic Books (in Korean).

6. Phillips, J. R., E. C. Clausen, J. L. Gaddy. 1994. Synthesis gas as substrate for the biological production of fuels and chemicals. Applied Biochemistry and Biotechnology 45/46: 145-157.

7. Yang, S. H. and J. S. Lee. 2004. Water and Wastewater Treatment-Design and Management. Dong-Hwa Technology Publisher (in Korean). 